\title{
AMPEROMETRIC MICRO-TITRATION OF STREPTOMYCIN AND DIHYDROSTREPTOMYCIN ${ }^{1}$
}

\author{
By JOHN B. CONN ANd SARA L. NORMAN
}

(From the Research Laboratories of Merck \& Co., Inc., Rahway, New Jersey)

With the introduction of dihydrostreptomycin into general use as an antibiotic, the development of a chemical assay procedure becomes desirable. Whereas adequate chemical methods exist for streptomycin, based on the characteristic maltol reaction $(1,2)$, dihydrostreptomycin does not respond similarly, and other techniques must be sought.

One property which is shared by both streptomycin and dihydrostreptomycin is the formation, under certain conditions, of sparingly soluble to insoluble salts with various anionic dyes, some of which are crystalline $(3,4)$. Since these dyes are polarographically reducible, it seemed possible that the precipitation reaction might be utilized in an amperometric titration procedure, which would have the advantage of being independent of other assay methods. When appropriate investigation was launched, it soon became apparent that no simple reaction was being dealt with. While a wide variety of acid azo dyes were found to give precipitates with dihydrostreptomycin salts in aqueous solution, the precipitates tended to be peptized by inorganic salts in concentration above a critical level or by excess dye, and further, would not separate at all unless the $\mathrm{pH}$ of the medium were held to a very narrow range. Inasmuch as polarographic methods require the presence of a supporting buffer electrolyte of concentration many times that of the component being measured, it was evident that dyes fulfilling the requirements would be rare.

Altogether, some seventy-odd dyes have been tested during the course of this work, of which 60 were commercial products, the remainder synthesized for the purpose. None of the commercial samples could be made to function in the desired manner; of the synthetics, those which showed promise were derived from diazotized 4-

1 Presented at the Second National Symposium on Recent Advances in Antibiotics Research held in Washington, D. C., April 11-12, 1949, under the auspices of the Antibiotics Study Section, National Institutes of Health, Public Health Service, Federal Security Agency. aminobiphenyl and diazotized pararosaniline, coupled with 1-naphthol-4-sulfonic acid.

The first of these, having the structure

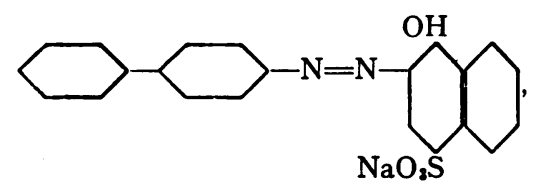

would precipitate dihydrostreptomycin in $0.1 \mathrm{~N}$

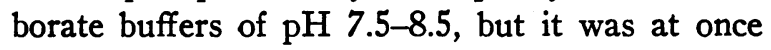
apparent that the composition of the precipitate was not the expected $\mathrm{BA}_{3}$, but contained much less dye. Moreover, a slow but steady drift toward zero occurred in the diffusion current after each addition of dye, once the equivalence point had been passed. Titrations carried out rapidly gave sharp apparent equivalence points, but the results were too erratic to be of value. After fruitless attempts to surmount the difficulty, which was caused by ion exchange between the precipitate and excess dye in solution, the use of this dye was abandoned.

$A$ priori, the solution to the problem of variable precipitate composition would be to select a dye which could give a dihydrostreptomycin salt of but one type; namely, one having three acidic functions. The representative most easily prepared by unequivocal method has the structure

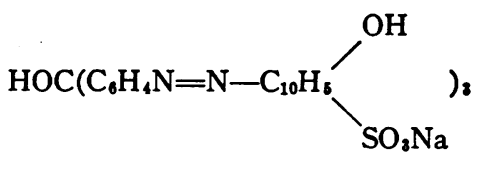

Trisodium tris-(naphtholazophenyl) carbinol trisulfonate

produced by diazotization of pararosaniline and coupling with 1-naphthol-4-sulfonic acid. The red dye is soluble in water up to $0.05 \mathrm{M}(5 \%)$ and precipitates dihydrostreptomycin in $0.01 \mathrm{M}$ triethanolamine citrate buffer, $\mathrm{pH} 2.8$, without any troublesome drift effects. (The use of triethanolamine citrate as supporting electrolyte was dictated by the peptizing action of the common inorganic cations.) The composition of the dihy- 
drostreptomycin dye precipitate is not exactly stoichiometric, but is reproducible under the conditions of titration.

\section{METHOD}

\section{Preparation of materials}

It is essential that pure intermediates be used in the preparation of the dye; otherwise mixtures of variable behavior result. Neither commercial fuchsine, which consists of a mixture of pararosaniline and its methyl and dimethyl homologues, nor technical grades of 1naphthol-4-sulfonic acid can be used. Eastman Kodak best grade pararosaniline base is suitable, while a pure grade of 1-naphthol-4-sulfonic acid is easily prepared from Eastman Kodak best grade 1-naphthylamine-4sulfonic acid via the Bucherer reaction (5).

Suspend $15.3 \mathrm{~g}$. (0.05 mole) finely pulverized pararosaniline base in $500 \mathrm{ml}$. water, cool to $5^{\circ}$, add $27 \mathrm{ml}$. conc. hydrochloric acid, and diazotize by dropwise addition of $10.4 \mathrm{~g}$. ( 0.15 mole) sodium nitrite in $100 \mathrm{ml}$. water over the period of one hour, with continuous stirring. At the end of the process, the solution should be orange and no particles of unreacted pararosaniline chloride should be present. The diazonium salt solution is poured with stirring into a solution of $37 \mathrm{~g}$. (slight excess over 0.15 mole) pure 1-naphthol-4-sulfonic acid in $500 \mathrm{ml}$. water containing $14 \mathrm{~g}$. sodium hydroxide, chilled to $5^{\circ}$. The dark red solution is stirred for one hour at $5^{\circ}$, filtered, and treated with $10 \mathrm{~g}$. ammonium chloride (to lower the $\mathrm{pH}$ ), after which it is allowed to stand at room temperature overnight. The dye solution is salted out with sodium chloride and centrifuged; the precipitate is suspended in sufficient water to render the mixture fluid, poured into a cellophane sac, and dialyzed against running water for 36-48 hours to remove diffusible electrolytes (it has not been found possible to date to crystallize the dye). The dialyzed solution is concentrated to dryness on the steam bath, and the vitreous green residue further dried at $100^{\circ}$. Yield, 50.4 g. (93\%). M.W., 1079.

For preparation of the titrating solution, $1.08 \mathrm{~g}$. $(0.001$ mole) is dissolved in $100 \mathrm{ml}$. water by warming; the solution is allowed to stand for two days, and then filtered through a layer of Celite to remove any insoluble particles.

Supporting buffer: Dissolve $29.8 \mathrm{~g}$. (0.2 mole) commercial triethanolamine and $21.0 \mathrm{~g}$. (0.1 mole) citric acid in 1 liter water and mix $400 \mathrm{ml}$. of this solution with 600 ml. $0.1 \mathrm{~N} \mathrm{HCl}$. This stock solution is diluted $1: 10$ with distilled water for use; the $\mathrm{pH}$ should be 2.8 .

\section{Procedure}

A Leeds and Northrup Electro-chemograph was used in conjunction with a Lingane-Laitinen cell (6), the equipment being housed in a room thermostated at $25^{\circ}$. The burette was a $1 \mathrm{ml}$. mercury-expulsion type of the Gilmont design.

The potentiometer is set at -0.8 v. vs. S.C.E., and recorder range at 10 micro-amperes. The cell is charged with 5-10 ml. buffer, and a sample of dihydrostreptomycin salt equivalent to $1-3 \mathrm{mg}$. base is introduced either in a small platinum boat or as a measured amount of solution. After nitrogen is passed through the solution for five minutes, the gas flow is switched to overpass and a chart tracing obtained after establishment of equilibrium, the chart being allowed to run until a straight line is drawn, stopping for convenience on a chart division. Nitrogen is once more passed through the solution, and $0.05 \mathrm{ml}$. of dye is introduced, after which a second chart tracing is obtained. This cycle of operations is repeated until the equivalence point has been passed and four or five current steps of about equal magnitude are obtained. The chart is read off, the current values corrected for volume change and the results plotted.

Standard preparations of streptomycin and dihydrostreptomycin salts are employed for calibration purposes. If streptomycin hydrochloride-calcium chloride double salt is used, the calcium chloride is best removed, so as to avoid any disturbing effect due to its presence. This is easily accomplished by stirring the solution of the sample with silver carbonate until the $\mathrm{pH}$ rises above 8; the solid is removed by centrifugation, washed, and the combined solution phases brought to $\mathrm{pH} 5$ with dilute acid.

\section{RESULTS AND DISCUSSION}

Table I lists data which have been collected on the titration of various dihydrostreptomycin salts.

In view of the usual difficulties of solvation and hygroscopicity which are encountered in dealing with these salts, the agreement is considered good, particularly since the amperometric titration depends on a property of the ion as a whole rather than any functional part.

TABLE I

Titration of dihydrostreptomycin salts

\begin{tabular}{l|c|c}
\hline \hline \multicolumn{1}{c|}{ Salt } & $\begin{array}{c}\text { Ampero- } \\
\text { metric } \\
\text { assay }\end{array}$ & Other assays \\
\hline Sulfate & 734 & \\
& 743 & \\
Chloride & 808 & \\
& 817 & \\
Sulfate & 760 & \\
& 765 & \\
Sulfate & 782 & 765 (Base titration) \\
& 790 & \\
Sulfate & 737 & 763 (Iodimetric) \\
& 749 & \\
Streptomycin Hydro- & 748 & 740 (Maltol) \\
chloride-Calcium & 733 & \\
Chloride & & \\
\hline
\end{tabular}


TABLE II

Stability of dihydrostreptomycin in normal sulfuric acid

\begin{tabular}{c|c|c}
\hline \hline Time (hours) & Temperature & Decomposition (\%) \\
\hline 1 & $100^{\circ}$ & 100 \\
23 & $25^{\circ}$ & 25 \\
95 & $25^{\circ}$ & 77 \\
\hline
\end{tabular}

In practice it is found that separate standardizations are required for streptomycin and dihydrostreptomycin salts, since the molecular compositions of the salts are neither exactly stoichiometric nor identical. This effect is not unexpected, in view of the colloidal nature of the anion.

Since, as has been previously pointed out, inorganic salts exert a strongly peptizing action on streptomycin and dihydrostreptomycin tris-(naphtholazophenyl) carbinol trisulfonate, applications of the amperometric assay are limited to those in which such salts are either absent or removable. For example, in case it is desired to use the method for a study of the stability of dihydrostreptomycin in aqueous solution at different $\mathrm{pH}$ 's and temperatures, the employment of sulfuric acid and barium hydroxide as acid and base permits removal of extraneous ions. The data in Table II on the acid stability of dihydrostreptomycin were obtained in this manner.

\section{SUM MARY}

Streptomycin and dihydrostreptomycin form water-insoluble salts with various anionic dyes; this property may be utilized for a precipitometric titration assay, provided that the characteristic tendency of the precipitate to be peptized by excess of indifferent salts can be overcome. In addition, unless the dye anion is trivalent, precipitates of variable composition are likely to be produced.

The dye formed by coupling diazotized pararosaniline with 1-naphthol-4-sulfonic acid precipitates streptomycin and dihydrostreptomycin quantitatively in $0.02 \mathrm{M}$ triethanolamine citrate buffer, $\mathrm{pH}$ 2.8. The polarograph is used in an amperometric titration procedure; an amount of streptomycin or dihydrostreptomycin salt corresponding to $1-3 \mathrm{mg}$. of base dissolved in $5-10 \mathrm{ml}$. buffer is titrated with $0.01 \mathrm{M}$ solution of dye, using a $1 \mathrm{ml}$. micro-burette; the polarograph is set at $-0.8 \mathrm{v}$. (vs. S.C.E.) and 10 micro-ampere range.

The titration is reproducible to better than $\pm 1 \%$. Using pure streptomycin and dihydrostreptomycin salts as standard, the method gives results in good agreement with other assay procedures.

\section{BIBLIOGRAPHY}

1. Schenck, J. R., and Spielman, M. A., The formation of maltol by the degradation of streptomycin. J. Am. Chem. Soc., 1945, 67, 2276.

2. Boxer, G. E., Jelinek, V. C., and Leghorn, P. M., The colorimetric determination of streptomycin in clinical preparations, urine, and broth. J. Biol. Chem., 1947, 169, 153.

3. Kuehl, F. A., Jr., Peck, R. L., Walti, A., and Folkers, K., Streptomyces antibiotics. I. Crystalline salts of streptomycin and streptothricin. Science, 1945, $102,34$.

4. Peck, R. L., Hoffhine, C. E., Jr., and Folkers, K., Streptomyces antibiotics. IX. Dihydrostreptomycin. J. Am. Chem. Soc., 1946, 68, 1390.

5. Fierz-David, H. E., and Blangey, L., Farbenchemie, Springer-Verlag, Wien, 1943, p. 174.

6. Lingane, J. J., and Laitinen, H. A., Cell and dropping electrode for polarographic analysis. Ind. Eng. Chem., Anal. Ed., 1939, 11, 504. 